\title{
Language Education in a Changing World
}


NEW PERSPECTIVES ON LANGUAGE AND EDUCATION

Founding Editor: Viv Edwards, University of Reading, UK

Series Editors: Phan Le Ha, University of Hawaii at Manoa, USA and Joel Windle, Monash University, Australia

Two decades of research and development in language and literacy education have yielded a broad, multidisciplinary focus. Yet education systems face constant economic and technological change, with attendant issues of identity and power, community and culture. This series will feature critical and interpretive, disciplinary and multidisciplinary perspectives on teaching and learning, language and literacy in new times.

All books in this series are externally peer-reviewed.

Full details of all the books in this series and of all our other publications can be found on http://www.multilingual-matters.com, or by writing to Multilingual Matters, St Nicholas House, 31-34 High Street, Bristol BS1 2AW, UK. 


\section{Language Education in a Changing World}

Challenges and Opportunities

Rod Bolitho and Richard Rossner 
DOI https://doi.org/10.21832/BOLITH7857

Library of Congress Cataloging in Publication Data

A catalog record for this book is available from the Library of Congress.

Names: Bolitho, Rod, editor. | Rossner, Richard, editor.

Title: Language Education in a Changing World: Challenges and

Opportunities/Edited by Rod Bolitho and Richard Rossner.

Description: Bristol; Blue Ridge Summit: Multilingual Matters, [2020] |

Series: New Perspectives on Language and Education: 79 | Includes

bibliographical references and index. | Summary: 'This book considers

the role of language education in a rapidly changing world. Drawing on

their extensive experience in language education, the authors consider

how students might be supported in developing the language awareness and

competences they need in order to participate fully and confidently in

our increasingly diverse societies' - Provided by publisher.

Identifiers: LCCN 2019047013 (print) | LCCN 2019047014 (ebook) | ISBN

9781788927857 (hardback) | ISBN 9781788927840 (paperback) | ISBN

9781788927864 (pdf) | ISBN 9781788927871 (epub) | ISBN 9781788927888

(kindle edition) Subjects: LCSH: Language and languages - Study and teaching. |

Language and education. | Language teachers - Training of.

Classification: LCC P51.L3446 2020 (print) | LCC P51 (ebook) | DDC

$418.0071-\mathrm{dc} 23$

LC record available at https://lccn.loc.gov/2019047013

LC ebook record available at https://lccn.loc.gov/2019047014

British Library Cataloguing in Publication Data

A catalogue entry for this book is available from the British Library.

ISBN-13: 978-1-78892-785-7 (hbk)

ISBN-13: 978-1-78892-784-0 (pbk)

\section{Multilingual Matters}

UK: St Nicholas House, 31-34 High Street, Bristol BS1 2AW, UK.

USA: NBN, Blue Ridge Summit, PA, USA.

Website: www.multilingual-matters.com

Twitter: Multi_Ling_Mat

Facebook: https:/www.facebook.com/multilingualmatters

Blog: www.channelviewpublications.wordpress.com

Copyright (C) 2020 Rod Bolitho and Richard Rossner.

All rights reserved. No part of this work may be reproduced in any form or by any means without permission in writing from the publisher.

The policy of Multilingual Matters/Channel View Publications is to use papers that are natural, renewable and recyclable products, made from wood grown in sustainable forests. In the manufacturing process of our books, and to further support our policy, preference is given to printers that have FSC and PEFC Chain of Custody certification. The FSC and/or PEFC logos will appear on those books where full certification has been granted to the printer concerned.

Typeset by Riverside Publishing Solutions.

Printed and bound in the UK by Short Run Press Ltd.

Printed and bound in the US by NBN. 